\title{
Emőd VERESS* \\ Sale of agricultural lands located outside built-up area in Romania: novelty elements introduced by Law no. 175/2020**
}

\begin{abstract}
Law no. 17/2014 on some measures to regulate the sale of agricultural land located outside the built-up area was adopted among other reasons to ensure food security and protect national interests in the exploitation of natural resources. These goals are perfectly justified and foreshadow changes in the global environment that will affect social and economic arrangements in the future with great impact. In this context, the importance of protecting agricultural land as a natural resource of central importance is a legitimate political goal. However, the methods used must be very carefully chosen in order to create a legal regime for the sale of agricultural land that respects, on the one hand, the requirements of European law and, on the other hand, fulfills the national interest as far as possible. The current legal regime, created by amending Law no. 17/2014 by Law no. 175/2020 for the amendment and completion of Law no. 17/2014, in force since 13 October 2020, creates a legal regime that raises more questions than it settles regarding the real challenges outlined above.
\end{abstract}

Keywords: Romania, agricultural land, preemption rights, prior authorisation of selling.

\section{General aspects}

Law no. 17/2014 on some measures to regulate the sale of agricultural land located outside the built-up area ${ }^{1}$ was adopted to ensure food security and protect national interests in exploiting natural resources. To achieve this goal, the law establishes important measures to regulate agricultural land sales outside the built-up area. Agricultural land located inside built-up areas is not subject to this regulation; these sales are subject to general dispositions of the law.

Emőd Veress: Sale of agricultural lands located outside built-up area in Romania: novelty elements introduced by Law no. 175/2020. Journal of Agricultural and Environmental Law ISSN 1788-6171, 2021 Vol. XVI No. 30 pp. 155-173, https://doi.org/10.21029/JAEL.2021.30.155

* PhD, full professor, Department of Law, Sapientia - Hungarian University of Transylvania, Romania, emod.veress@sapientia.ro, ORCID: 0000-0003-2769-5343.

** The research of this article was supported by the Ferenc Mádl Institute of Comparative Law.

${ }^{1}$ Law no. 17/2014 regarding some measures to regulate the sale-purchase of agricultural lands located outside the built-up area and to amend Law no. 268/2001 on the privatization of companies holding public and privately owned state lands for agricultural use and the establishment of the State Domains Agency, published in the Official Gazette, Part I no. 178 of March 12, 2014. 
This special legal regime of the circulation of agricultural lands located outside the built-up area has recently been substantially modified by the provisions of Law no. $175 / 2020$ for the amendment and completion of Law no. 17/2014, amendments that came into force starting on 13 October $2020 .^{2}$

I intend to analyse the legal regime of the sale of these agricultural lands, with special regard to the new amendments to this legal regime through the provisions of Law no. 175/2020. The legislation is recent, and in the context of the COVID-19 pandemic has not yet facilitated scientific opinions and illuminative jurisprudence. ${ }^{3}$ However, even under these circumstances, it is worth examining this new, specific legal regime.

\section{Personal scope of Law no. 17/2014}

The provisions of Law no. 17/2014 apply to Romanian citizens, to the citizens of a Member State of the European Union, of the states that are party to the Agreement on the European Economic Area (ASEE), or of the Swiss Confederation, as well as to stateless persons domiciled in Romania, in a Member State of the European Union, in a state that is a party to the ASEE or in the Swiss Confederation, as well as to legal persons having Romanian nationality, of a Member State of the European Union, of the states that are part of the ASEE, or of the Swiss Confederation. ${ }^{4}$

A third-country national and a stateless person domiciled in a third state and legal persons with the nationality of a third state may acquire ownership of agricultural land located outside the built-up area under the conditions regulated by international treaties, based on reciprocity. ${ }^{5}$ Consequently, if the legal norms recognise the citizens of third countries and to legal persons having headquarters in a third state, the right to acquire the right of ownership over the lands in general, then Law no. 17/2014 becomes applicable for the acquisition of agricultural lands located outside the built-up area and in the case of these persons as well.

\footnotetext{
${ }^{2}$ Law no. 175/2020 for the amendment and completion of Law no. 17/2014 regarding some measures to regulate the sale-purchase of agricultural lands located outside the built-up area and to amend Law no. 268/2001 regarding the privatization of the commercial companies that hold in administration lands of public and private property of the state with agricultural destination and the establishment of the State Domains Agency, published in the Official Gazette, Part I no. 741 of 14 August 2020.

${ }^{3}$ Some regulatory deficiencies have already been identified when Law no. 175/2020 was still in the project phase. See Jora \& Ciochină-Barbu 2018, 9-18. By referring to European law, the provisions of this new regulation were analyzed by Prescure \& Spîrchez 2020, 21-40., respectively by Durnescu (Prăjanu) 2020, 37-57.

${ }^{4}$ For a general assessment of the cross-border acquisition of agricultural land, see Szilágyi 2017, 214-250.

5 According to art. 44 para. (2) of the Romanian Constitution, foreign citizens and stateless persons may acquire the right of private ownership over land only under the conditions resulting from Romania's accession to the European Union and other international treaties to which Romania is a party, based on reciprocity, in the conditions provided by an organic law, as well as by legal inheritance.
} 
On the other hand, the law does not apply to the sales of agricultural lands located outside the built-up area that belong to the private domain of local or county interests of the administrative-territorial units. ${ }^{6}$

\section{Special limitations: agricultural land located in the border area and adjacent to special objectives}

Law no. 17/2014 introduced some special limitations for agricultural lands located outside the town at a depth of $30 \mathrm{~km}$ from the state border and the Black Sea coast, inland, as well as those located outside the town at a distance of up to 2,400 m from the special objectives. For the alienation of these lands by sale, the Ministry of National Defence's specific approval is required, issued following consultation with the state bodies with attributions in the field of national security.

However, these limitations do not apply to preemptors; that is, if the buyer is the holder of a preemption right, approval is no longer necessary. The law does not specify which preemptors are exempted. The right of preemption may be established by law or convention. If the owner has recognised the right of preemption through a contract in favour of a person who subsequently exercises this right of preemption of a conventional nature, is no specific opinion from the Ministry of National Defence required? In favour of a positive answer, we can invoke the principle ubi lex non distinguit, nec nos distinguere debemus. Indeed, the law makes no distinction between preemptors according to the legal or conventional source of the right of preemption. Thus, by establishing a preemption right by the parties' agreement, the need for approval can be removed. However, because the provisions of Law no. 17/2014 establish special norms that form a unitary whole, I think that the removal of the approval of the Ministry of National Defence refers only to the preemptors whose rights have their origin in the text of Law no. 17/2014. Consequently, the holder of a conventional right of preemption cannot invoke the fact that the approval established by Law no. 17/2014 is not necessary. In addition, a preemption right would be invoked based on another law other than Law no. 17/2014. Applying the argument of the unity of conception of the law would also require approval in the case of these preemptors. Instead, as the possible speculative element (namely the situation in which the cause of establishing the conventional right of preemption would be the removal of the approval on the sale by the Ministry of National Defence) in the case of a legal right of preemption is missing. In this context we could recognise that the contract between the seller and the preemptor can be validly concluded in the absence of approval in the case of any legal right of preemption. However, to resolve this issue definitively, the following amendment would be required in the law's text: it should be specified that these limitations do not apply to preemptors whose rights have their origin in the law.

Approvals must be communicated within 20 working days of request registration by the seller. In the case of non-fulfillment of this obligation to issue the approval, it is considered favourable, that is, the law establishes a positive tacit approval procedure for non-compliance with the term of 20 working days.

6 Article 20 para. (3) of Law no. of Law no. 17/2014, in the form established by Law no. 138/2014. 
4. Special limitations: agricultural lands where there are archaeological sites

Agricultural lands located outside the built-up area, where there are archaeological sites in which areas with spotted archaeological patrimony or areas with accidentally highlighted archaeological potential have been established, can be alienated by sale only with the specific approval of the Ministry of Culture, respectively, of the deconcentrated public services, as the case may be issued within 20 working days from the registration of the request by the seller. As in the previous case, in the event of noncompliance with this obligation, approval shall be deemed favourable.

\section{State intervention in the movement of agricultural land outside the built-up area}

Undoubtedly, the new regulation is far from what is expected to solve the agricultural land movement. If the substantive issue, namely the creation of a special regime for the movement of agricultural land located outside the built-up area in accordance with the public interest, is correct and fair, the administrative impediments created are excessive. The intention is correct, but the chosen path must be criticised. Although European rules in this area have not yet been fully clarified, some new regime elements contradict European law.

The establishment of any right of preemption by law is undoubtedly a limitation of the contractual freedom and the prerogatives of the holder of the property right. These limitations must be justified and proportionate.

\section{Holders of the right of preemption established by Law no. 17/2014, in the form amended by Law no. 175/2020}

In the initial form of the law, the alienation, by sale, of the agricultural lands located outside the built-up area was allowed with the observance of the preemption rights of the co-owners, lessees, neighbouring owners, as well as of the Romanian state, through the State Domains Agency, in this order, on equal terms.

Law no. 175/2020 modifies and expands the scope of preemptors, creating seven categories of preemptors: (a) Preemptors of rank I: co-owners, first-degree relatives, spouses, relatives, and brothers-in-law up to and including the third degree; (b) Rank II preemptors: owners of agricultural investments to cultivate trees, vines, hops, exclusively private irrigation, and/or lessees. If on the lands subject to sale there are agricultural investments for tree crops, vines, hops, and for irrigation, the owners of these investments have priority in the purchase of these lands; (c) Rank III preemptors: The owners and/or lessees of the agricultural lands adjacent to the land subject to sale, in compliance with some requirements to be analysed in the next subchapter; (d) Preemptors of rank IV: young farmers; (e) Preemptors of rank V: the Academy of Agricultural and Forestry Sciences 'Gheorghe Ionescu-Șișești' and the research- 
development units in the fields of agriculture, forestry, and food industry, ${ }^{7}$ as well as the educational institutions with agricultural profile, in order to buy agricultural lands located outside the built-up area with the destination strictly necessary for agricultural research, located in the vicinity of existing lots in their patrimony; (f) Preemptors of rank VI: natural persons with domiciles/residences located in the administrativeterritorial units where the land is located or in the neighbouring administrativeterritorial units; ${ }^{8}$ (g) Preemptors of rank VII: the Romanian state, through the State Domains Agency.

\section{Interpretation issues raised by current regulations}

The first question that arises is how is the conflict between preemptors of identical rank resolved? For example, what happens when both the co-owner and the seller's child want to buy the agricultural land, or how is the conflict between the seller's child and the seller's brother (second-degree relative) resolved? In both examples, all the people shown have the quality of preemptor of rank I; we are not in the presence of a preemptor of higher rank and one of lower rank. Law no. 17/2014 is silent and does not offer a solution to the competition between identical-rank preemptors.

Thus, we must rely on the provisions contained in Article 1734 of the Civil Code, which regulates the competition between preemptors. ${ }^{9}$ The provisions of Article 1734 have mandatory character. ${ }^{10}$

According to this legal text, if several holders have exercised their preemption on the same good, the contract of sale is considered concluded: (a) with the holder of the legal right of preemption when they compete with holders of conventional preemption rights; (b) with the holder of the legal right of preemption chosen by the seller when he competes with other holders of some legal rights of preemption; (c) if the property is immovable, with the holder of the conventional right of preemption, which was first registered in the land book when it competes with other holders of conventional preemption rights; and (d) if the good is movable, with the holder of the conventional preemption right having the oldest certain date, when it competes with other holders of conventional preemption rights.

Here, we are not in the competition between a legal right holder and the holder of a conventional right of preemption. Thus, the hypothesis provided in let. (a) above does not demonstrate its applicability. Nor does let. (c) apply in the analysed situation because the norm resolves the conflict between the conventional preemption rights

\footnotetext{
7 Organized and regulated by Law no. 45/2009 on the organization and functioning of the Academy of Agricultural and Forestry Sciences 'Gheorghe Ionescu-Șișești' and the researchdevelopment system in the fields of agriculture, forestry, and food industry, with subsequent amendments and completions.

${ }^{8}$ We notice that this category of pre-emptors is vast. There is no difference between the persons who have their domicile in the administrative-territorial unit where the land for sale is located or in the neighboring administrative-territorial units.

${ }_{9}$ According to art. 8 of Law no. 17/2014, the legal provisions regarding the pre-emption right exercise are completed with the general law's provisions.

10 Article 1734 para. (2) Civil Code establishes that any clause contrary to the regulations contained in this rule is considered unwritten.
} 
holders, and we exclude let. (d) because it refers to the preemption exercised in the case of movable property. Thus, the only applicable norm is art. 1734 para. (1) let. (b), which establishes that in the case of a competition between legal preemptors (of the same rank), the seller is the one who has the (unilateral) right to choose between the holders of the legal preemption right. The seller in the situation shown can choose at his discretion the buyer, preferring, for example, the brother over his child, both preemptors of rank I., etc. ${ }^{11}$

The second issue refers to a legal text that remains unchanged by Law no. 175/2020. Article 20 para. (2) of Law no. 17/2014 establishes that "the provisions of this law do not apply to alienations between co-owners, spouses, relatives and brothers-in-law up to and including the third degree." The law also stipulates that co-owners, first-degree relatives, spouses, relatives, and brothers-in-law up to and including the third degree are firstdegree preemptors. Is there a conflict in the text of the law, or is it a deliberate option? This is difficult to establish. If we interpret the two texts as conflicting, then we can say that art. 20 para. (2) of Law no. 17/2014 was implicitly repealed by Law no. 175/2020. I do not think that this is the right interpretation. I consider that the two texts refer to distinct situations, as follows: (a) In reality, the owner can sell freely under the conditions of art. 20 para. (2) of Law no. 17/2014 its agricultural land located outside the built-up area, if the buyer is a co-owner, husband, relative, or brother-in-law up to and including the third degree, without any obligation to submit to the special legal regime established by Law no. 17/2014. From this circle of buyers, the owner can freely choose the buyer because, in this context, the sale acquires intuitu personae character; the determining reason for the sale is not limited simply to obtaining a price. Thus, preserving the family property is encouraged and a correct intention is pursued by the legislator by establishing these legal provisions. Moreover, if the scope was to repeal art. 20 para. (2) of Law no. 17/2014, then Law no. 175/2020 could have proceeded to an express repeal, so we can presume that the legislator intended to keep this regulation. ${ }^{12}$ (b) If the owner has not negotiated and concluded a contract with the persons provided above, but follows the specific procedure established by Law no. $17 / 2014$, then the law recognises the status of the first-rank preemptor for co-owners, first-degree relatives, spouses, relatives, and brothers-in-law up to and including the third degree, protecting these persons even against the will of the owner and other potential buyers.

11 The correct solution was also embraced by the Methodological Norms, which, in art. 9 para. (1) stipulate that "in the case of a competition between preemptors within the same rank, the seller chooses the preemptor and communicates his name to the mayor's office." See the Methodological Norms regarding the exercise by the Ministry of Agriculture and Rural Development of the attributions incumbent on it for the application of title I of Law no. 17/2014, published in the Official Gazette, Part I no. 127 of February 8, 2021 (hereinafter: Methodological Norms).

12 This interpretation is also adopted by the relevant ministry, which in the Methodological Norms, in art. 7, provided the following: "(1) In the situation where the seller has not requested the display of the sale offer at the mayor's office, and the quality of buyer is held by the persons mentioned in art. 20 para. (2) of the law, at the conclusion of the sales contracts, the presentation of the approvals provided by law is not required. (2) In the situation where the seller requested the display of the sale offer, the persons mentioned it in art. 20 para. (2) of the law may exercise the right of preemption, in which case the contract of sale is concluded with the request of the approvals provided by law." 
A third problem is the artificial creation of the right of preemption for a potential buyer agreed upon by the seller. The easiest method was the conclusion of an agricultural lease, in which case the quality of lessee offered the right of preemption of rank II to the potential buyer. However, the law, absolutely correct, through detailed rules makes the use of these fraudulent leases particularly difficult. There are several conditions imposed on the lessee in order to have a right of preemption on the leased land, soma conditions even questionable under EU law: (a) The lessee wishing to buy the leased agricultural land located outside the built-up area must have this quality under a valid lease contract concluded and registered according to the legal provisions at least one year before the date of posting the sale offer at the town hall. (b) In the case of natural person lessees, they must prove the domicile/residence located in the national territory for a period of five years prior to the registration of the offer for sale of agricultural lands located outside the built-up area. (c) In the case of lessees that are legal entities, the natural person members of such a legal person have to prove that their domicile/residence was located in the national territory for a period of five years before the registration of the offer for sale of agricultural lands located outside the built-up area. (d) In the case of lessees that are legal entities, having as a member another legal entity, the shareholders holding control of this second entity have to prove that the registered office/secondary office is located in the national territory and was established for a period of five years before the registration of the offer to sell agricultural land outside the built-up area.

Instead, a simulated sale could be orchestrated within a forced execution procedure because the provisions of Law no. 17/2014 do not apply in enforcement proceedings and sales contracts concluded as a result of the fulfilment of public tender formalities, as is the case of those carried out in the insolvency proceedings. ${ }^{13}$ The situation of a simulated sale in the form of a donation also remains open, but the sanction applicable to these fraudulent contracts, as we will see, is that of nullity. Fraud can also be staged using an exchange contract. For example, if an agricultural land located outside the built-up area is changed to shares issued by a listed company, thus having maximum marketability, we are practically in the presence of an operation that is more like a sale than an exchange. Another possible method of circumventing legal provisions is to establish a unipersonal limited liability company, in which the owner provides the agricultural land. However, after the company's registration, the shares are alienated to the buyer, with respect to which the regime established by the law analysed here does not apply. In addition, a giving in payment (datio in solutum ${ }^{14}$ ) can be used to achieve the transfer of property: the owner contracts a loan (practically collects the price), and instead of repaying the loan, he gives in payment the agricultural land, extinguishing the debt. Given the severe restriction on agricultural land movement outside the built-up area (see also the following subchapters), such procedures will certainly increase.

13 See art. 20 para. (3) of Law no. of Law no. 17/2014, in the form established by Law no. $138 / 2014$.

${ }^{14}$ Discharge of debt by giving something different, in agreement with the creditor. 
The fourth problem is that of neighbouring owners or neighbouring lessees and preemptors of rank III. After establishing that the owner or lessee of the agricultural land adjacent to the land subject to sale has the quality of preemptors, the normative text refers to the specific conditions under which the quality of lessee must be held: similarly to the rank II lessee. It is not very clear wheteher this reference rule applies only to lessees or neighbouring owners. If we accept the interpretation that this reference rule extends the legal requirements to neighbouring owners, then not every neighbouring owner or lessee has the right of preemption, but only the one who holds this quality for at least one year before the date of posting the sale offer at the town hall, and also meets the domicile/residence requirements set out above. I believe that the legislator did not want to extend these specific requirements to neighbouring owners, even if the text is ambiguous, but wanted to impose identical conditions only for lessees, regardless of whether they are lessees of the land for sale (preemptors of rank II) or lessees of neighbouring agricultural lands (rank III preemptors).

What happens if several neighbours want to exercise their preemption rights at the same time? The law does not allow a free choice of the seller but imposes mandatory criteria that carry out abstract economic reasoning. Has priority to purchase (a) the owner of a neighbouring agricultural land that has a common border with the largest side of the land that is the object of the sale offer; (b) if the land that is the object of the sale offer has two large sides or all equal sides, priority has the owner of neighbouring agricultural land who is a young farmer, ${ }^{15}$ who has his domicile/residence located in the national territory on a period of at least one year before the registration of the offer for sale of agricultural lands located outside the built-up area; (c) the owners of neighbouring agricultural land who have a common border with the land that is the object of the sale offer, in descending order of the length of the common border with the land in question; and (d) if the large side or one of the equal sides of the land that is the object of the sale offer has a common border with land located within another administrative-territorial unit, priority to the purchase of the land has the owner of neighbouring agricultural land with domicile/residence within the administrative-territorial unit where the land is located.

I interpret this legal text in the sense that within the category of rank III preemptors, there is in practice a specific order of priority: the owner of the neighbouring land is preferred to the lessee of the neighbouring land. In this sense, however, constant clarifying jurisprudence would be welcome.

15 If several young farmers exercise the right of preemption, the young farmer who carries out activities in animal husbandry has priority in the purchase of the land subject to sale, respecting the condition regarding the domicile/residence established on the national territory for a period of at least one year before registration of the offer for sale of agricultural land located outside the built-up area. See art. 4 para. (3) of Law no. 17/2014, in the form established by Law no. $175 / 2020$. The notion of a young farmer is the one envisaged by EU law: a person up to the age of 40 who has the appropriate professional skills and qualifications. See art. 2 para. (1) lit. n) of Regulation (EU) no. 1,305 / 2013 on support for rural development provided by the European Agricultural Fund for Rural Development (EAFRD). 
A final issue concerns the issue of conflict of laws in the case of agricultural lands located outside the built-up area on which classified archaeological sites are located. Which of the laws will have priority: Law no. 14/2014 or Law no. 422/2001 on historical monument protection? In this case, the conflict is resolved correctly: the preemption regulation in Law no. 422/2001 is applied.

\section{Procedural rules on the exercise of the right of preemption}

In its current form, the legal regime for exercising the right to preemption is as follows: ${ }^{16}$ (a) The seller registers at the mayors' office within the administrativeterritorial unit where the land is located an application requesting the display of the sale offer of the agricultural land located outside the built-up area, in order to bring it to the notice of the preemptors. (b) The application shall be accompanied by an offer to sell agricultural land and supporting documents. ${ }^{17}$ (c) Within five working days from the date of registration of the application, the mayor's office has an obligation to display for 45 working days the sale offer at its headquarters and, as the case may be, on its website. (d) The mayor's office has an obligation to send to the structure within the central apparatus of the Ministry of Agriculture and Rural Development (hereinafter referred to as the central structure), respectively, to the county or Bucharest agriculture directorates (hereinafter referred to as territorial structures), as appropriate, and to the Agency of State Domains a file containing a list of preemptors, copies of the application for displaying the sale offer and the proving documents, and the minutes of displaying the offer, within five working days from the date of registration of the documentation. (e) For the purpose of extended transparency, within three working days from the registration of the file, the central structure, and the territorial structures, as the case may be, have an obligation to display on their own sites the sale offer, for 15 days. (f) Within 10 working days from the date of registration of the application, the mayor's office has an obligation to notify the holders of the preemption right, at their domicile, residence, or, as the case may be, their headquarters, the registration of the sale offer; if the holders of the preemption right cannot be contacted, the notification will be made by posting at the mayor's office or on the mayor's office website. If the area of land that is the subject of the sale intention is at the border of two administrative territories, the mayor's office will notify the local public authority with which it adjoins, which in turn will notify the holders of preemption rights. (g) The holder of the preemption right must, within 45 working days, express in writing his intention to buy, communicate the acceptance of the seller's offer, and register it at the mayor's office where it was displayed. The sanction that intervenes in the case of non-observance of this term is forfeiture. ${ }^{18}$ The mayor's office will display, including on its website, within three working days from the registration of the acceptance of the sale offer, the data from the offer and will send them for display on the website of the central structure or territorial structures, as appropriate. The communication of the acceptance of the seller's offer is registered at the mayor's office by the holder of the

16 Art. 6-8 of Law no. 17/2014, in the form established by Law no. 175/2020.

${ }^{17}$ See art. 5 of the Methodological Norms.

${ }^{18}$ See art. 6 para. (1) of the Methodological Norms. 
preemption right accompanied by the supporting documents. ${ }^{19}$ (h) If, within 45 working days, several preemptors of different ranks express in writing their intention to purchase, at the same price and under the same conditions, the legally established order shall apply. (i) Within 45 working days, several preemptors of the same rank express their intention to purchase in writing, and no preemptor of higher rank has accepted the offer, at the same price and under the same conditions, the legally established order shall be applicable. (j) If within 45 working days, a lower-ranking preemptor offers a higher price than the one in the sale offer or the one offered by the other higher-ranking preemptors to him who accepts the offer, the seller may resume the procedure with the registration of the new price. The resumed procedure will be carried out only once, within 10 days from the fulfilment of the term of 45 working days previously analysed. $(\mathrm{k})$ Within three working days from the registration of the communication of acceptance of the sale offer, the mayor's office has an obligation to transmit to the central structure, respectively, to the territorial structures, as the case may be, the identification data of the preemptors, potential buyers, in order to verify the legal conditions.

\section{Modification of the sale offer and acceptance}

The law contains rules derogating from the general rules relating to the offer to contract and the binding (irrevocable) nature of the offer. Under the conditions of Art. 1191 of the Civil Code, the offer is irrevocable as soon as its author maintains it for a certain period. The offer is also irrevocable when it can be considered based on the parties' agreement, the established practices between them, the negotiations, the content of the offer, or the usages. The declaration of the revocation of an irrevocable offer has no effect. Moreover, the offer without a deadline for acceptance addressed to a person who is not present must be maintained within a reasonable time, depending on the circumstances, for the recipient to receive it, analyse it, and send the acceptance. The offeror is liable for the damage caused by the offer's revocation before the expiration of the reasonable term. The revocation of the offer does not prevent the contract's conclusion unless it reaches the recipient before the offeror receives the acceptance or, as the case may be, before committing the act or fact that determines the conclusion of the contract (art. 1193 Civil Code). Within the procedure established by Law no. 17/2014, we are in the presence of an offer with a term established by law.

However, the special law makes it possible to modify the sales offer already published. If within 45 working days provided for the exercise of the right of preemption, respectively, within 10 days provided for the resumed procedure, the seller changes the data entered in the sale offer, and resumes the registration procedure from scratch.

The seller also has the right to withdraw his offer to sell. ${ }^{20}$ Before the fulfillment of the term of 45 working days provided for the exercise of the preemption right, the seller may submit to the mayor's office where the request for display of the sale offer was registered an application requesting the withdrawal of the offer.

${ }^{19}$ See art. art. 6 of the Methodological Norms.

20 Art. 7 of Law no. 17/2014, in the form established by Law no. 175/2020. 
In this case, the mayor's office will conclude a report cancelling the procedure provided by this law and will communicate a copy of it to the central structure or territorial structure, as the case may be, to the State Domains Agency.

Thus, we are not in the presence of a veritable offer in the sense of the Civil Code, but only in the presence of an invitation to negotiate addressed to the preemptors.

Symmetrically, the law also allows the preemptor to waive his own acceptance of the offer before fulfilling the 45 working days term provided to exercise the preemption right. If one of the holders of the preemption right who has expressed their acceptance of the offer registers at the mayor's office, a request to waive the communication of acceptance, the preemptors' legal order applies.

Consequently, the exercise of the right of preemption generally leads to the selection of a buyer according to the law but can be perceived as a special selection procedure for the buyers, and the contract will be born when the agreement of will takes, before the notary public, the authentic form.

\section{Priority right to purchase: legal restrictions on the movement of agricultural land located outside the built-up area if the right of preemption has not been exercised}

Law no. 175/2020 introduces other new restrictions on the legal movement of agricultural land, in addition to the new regulation of preemption rights, which become applicable if none of the holders of the preemption right would exercise their rights. In this case, agricultural land may be alienated only to a natural or legal person who meets certain requirements imposed by law.

In the case of natural persons, these cumulative requirements are the following: ${ }^{21}$ (a) the natural person concerned to have his domicile/residence located in the national territory for a period of at least five years before the registration of the sale offer; (b) to carry out agricultural activities on the national territory for a period of at least five years before the registration of this offer; and (c) to be registered by the Romanian fiscal authorities at least five years before registering the offer to sell agricultural lands located outside the built-up area.

In the case of legal persons, the cumulative legal conditions are more complicated: (a) the legal person concerned must have its registered office and/or secondary headquarters located in the national territory for a period of at least five years before the registration of the sale offer; (b) to carry out agricultural activities on the national territory for a period of at least five years before the registration of the offer for sale of agricultural lands located outside the built-up area. (c) to present the documents showing that, from the total income of the last five fiscal years, at least $75 \%$ represents income from agricultural activities, as provided by Law no. 227/2015 on the Fiscal Code, with subsequent amendments and completions, classified according to the NACE (European Classification of Economic Activities) code by the order of the Minister of Agriculture and Rural Development. (d) the associate/shareholder who holds the control of the company shall have domicile located on the national territory

${ }^{21}$ Art. 4 of Law no. 17/2014, in the form established by Law no. 175/2020. 
for a period of at least five years before the registration of the offer for sale of the agricultural lands located outside the built-up area. (e) if, in the structure of legal entities, the associates/shareholders who control the company are other legal entities, the associates/shareholders who control the company to prove the domicile located in the national territory for a period of at least five years before the registration of the offer sale of agricultural land located outside the built-up areas.

In terms of the procedure to be followed, in case of non-exercise of the right of preemption by legal holders, potential buyers can submit to the mayor's office a file containing the documents proving the fulfilment of the above conditions within 30 days from the expiration of 45 working days established for the exercise of the right of preemption. The mayors' office will send the file to the central structure, respectively, to the territorial structures, as the case may be, within five working days from the date of registration of the documentation.

The law refers first to natural persons and later to legal persons, but it cannot be deduced from the normative text that the legislator would prefer natural persons to legal persons. For both situations, the law simply establishes the existence of the situation "in which the holders of the right of preemption do not express their intention to buy the land." In my opinion, the correct interpretation of the legal texts is that the selling owner has the freedom to choose any bidder, whether natural or legal person, who meets the conditions analysed above. ${ }^{22}$

Unlike the right of preemption, the priority right to purchase is not a genuine option right. The establishment of this right seems to be only a restriction on contractual freedom. These provisions limit the owner to choose the buyer from a limited circle of people (favoured buyers) who meet certain criteria set by the legislator, which thus wants to direct transfers of property rights on agricultural lands located outside the built-up area in a certain direction.

The sale of the land at a lower price than the one requested in the initial sale offer, in more advantageous conditions in favour of the buyer than those shown in this or with the non-observance of the legal conditions regarding the person of the buyer attracts nullity. 23

\section{Freedom to choose the buyer}

In the procedure established by Law no. $17 / 2014$, full freedom in choosing the buyer is regained only when neither the holders of the right of preemption nor the legally favoured buyers exercise their rights within the legal term. Thus, in the case of non-exercise of the right of preemption, and if none of the potential favoured buyers, within the legal term, meets the conditions to be able to buy the agricultural land located outside the built-up area, the sale can be made to any natural or legal person.

\footnotetext{
22 This interpretation is also reflected in the Methodological Norms, which state that the seller chooses the buyer and communicates his/her name to the mayor's office in the case of competition between potential buyers. See art. 9 para. (2) of the Methodological Norms. ${ }^{23}$ Article 7 para. (8) of Law no. 17/2014, in the form established by Law no. 175/2020.
} 
From a procedural point of view, the freedom to choose the buyer requires a report on completing the procedure issued by the mayor's office. The minutes shall be issued to the seller and communicated to the central structure or territorial structures, as the case may be. This report certifies that no preemptor or person entitled to a priority purchase has exercised their rights and has not wished to buy the agricultural land.

\section{Overtaxing of speculative sales}

Another novelty element brought by Law no. 175/2020 is the overtaxation of speculative sales. ${ }^{24}$ The owners of agricultural lands located outside the built-up area have an obligation to use them exclusively to carry out agricultural activities from the date of purchase. It is considered speculative to sell the land if that takes place within eight years of purchase. In this situation, the legislator operates with an absolute presumption of resale purchase, subject to overtaxation.

Thus, agricultural land located outside the built-up area can be alienated, by sale, eight years before the date of purchase, with the obligation to pay $80 \%$ tax on the amount representing the difference between the sale price and the purchase price, based on the notaries grid in that period. Consequently, would the tax base not be determined based on the parties' contract price, but ratherbased on notarial estimates? Or do these rules apply only if the contract prices are lower than those in the notarial grids? I am in favour of the second interpretation.

In the case of direct or indirect alienation, before 8 years from the moment of purchase, of the control package of shares in the companies that own agricultural lands located outside the built-up area and which represent more than $25 \%$ of their assets, the seller will have an obligation to pay a tax of $80 \%$ of the difference in the value of the land calculated based on the notaries' grid between the time of acquisition of the land and the time of alienation of the control package. In this case, the profit tax on the difference in the value of the shares or shares sold will be applied on a reduced basis in proportion to the percentage of the agricultural land share in question in the fixed assets, any double taxation being prohibited. These provisions do not apply to the reorganisation or reallocation of assets within the same group of companies..$^{25}$

Interestingly, the law for these situations refers to the provisions of Article 16 of the law, that is, sanction the contracts in question with absolute nullity. It is not easy to determine when this sanction can be applied. Interestingly, the violation of some rules of fiscal law attracts civil nullity. The legislator probably thought that sales for which the tax is not paid would be null and void, given the situations in which the total disguise simulation method would be used (a publicly simulated secret sale is concluded as a donation) or the partial disguise simulation (declaration in the contract at a price lower than that actually agreed by the parties).

${ }^{24}$ Art. 4 of Law no. 17/2014, in the form established by Law no. 175/2020.

25 Probably the legislator considered sales within a group of companies. 


\section{Application of an administrative law regime for the control of land movement and sanctioning the violation of the civil law norms}

The legal circulation of agricultural land is currently subject not only to a legal regime of civil law but also to a regime of administrative law, which can be highlighted by the special role of the mayors' offices, on the one hand, and the Ministry of Agriculture and Rural Development, on the other hand.

The Ministry of Agriculture and Rural Development, together with subordinate structures, as the case may be: (a) ensures the publication of sales offers on its website; (b) ensures the verification of the exercise of the preemption right; (c) verifies the fulfilment of the legal conditions of sale by the preemptor or potential buyer, provided by the present law; (d) issues the approvals provided by law necessary for concluding the contract for the sale of agricultural lands located outside the built-up area; (e) ascertains contraventions and applies the sanctions provided by law; and (f) draws up, updates, and administers the Single National Register on agricultural land movement and destinations located outside the built-up area. ${ }^{26}$

The contract for sale in authentic form can be concluded only in possession of a final approval issued by the territorial structures for lands with an area of up to 30 ha inclusive, and for lands with an area of over 30 ha, by the central structure. ${ }^{27}$ If the seller or preemptor dies before the conclusion of the contract of sale, approval is cancelled. Therefore, this approval is not transferable to heirs.

This approval is practically authorisation, but the administrative authority does not have its own assessment rights. The control is limited to verifying the fulfilment of legality conditions. If following the verifications by the central structure, respectively, the territorial structures, as the case may be, it is found that the chosen preemptor or potential buyer does not meet the conditions provided by this law, a negative opinion will be issued.

For the control, the administrative authority has a term of 10 working days from the expiration of the term of 45 working days provided for the exercise of the preemption right or from the expiration of the term of 10 days in case of resumption of the procedure for modifying the offer, that is, the situation analysed above. In case of fulfilling the legal conditions, within five working days from the term's expiration for verification, the central structure, respectively, the territorial structures, as the case may be, will issue the approval/final approval necessary for concluding the sale contract.

If no preemptor has expressed its intention to purchase, the verification of the fulfilment of the conditions by the potential favoured buyers will be done by the central structure, respectively, by the territorial structures at the location of the land, within 10 working days upon transmission of the file by the mayor's office.

\footnotetext{
26 The register is maintained electronically. The local public administration authorities and the National Agency for Cadastre and Real Estate Registry have an obligation to transmit to the Ministry of Agriculture and Rural Development the data and information regarding the procedural stages, cadastral documents, and transfer deeds of ownership of agricultural land located outside built-up areas. See art. 12 para. (2)-(6) of Law no. 17/2014, in the form established by Law no. 175/2020.

${ }^{27}$ The rule also applies if the court rules the transfer of ownership based on a pre-contract.
} 
The administrative law regime is accentuated by the fact that, along with the specific sanctions of civil law (nullity, compensations), the legal provisions' violation is also sanctioned by administrative law sanctions. Thus, the following facts constitute contravention: 28 (a) the sale of agricultural lands located outside the built-up area, where there are archaeological sites, where areas with spotted archaeological patrimony or areas with archaeological potential accidentally highlighted have been established, without the specific approval of the Ministry of Culture, respectively of its deconcentrated public services, after case; (b) the sale of agricultural lands located outside the built-up area without the specific approval of the Ministry of National Defence, if this situation was noted in the land book at the date of requesting the land book extract for authentication; (c) the sale of agricultural lands located outside the built-up area without the approvals of the central structure, respectively, of the territorial structures of the Ministry of Agriculture and Rural Development, as the case may be; (d) non-compliance with the right of preemption and the rights of favoured buyers; non-compliance with the norms regarding the special taxation of alienations of agricultural lands considered speculative; and (e) non-compliance by the mayor's office with the obligations regarding the display of the sale offer, transmission of the file to the central or territorial structure, notification of the preemption rights holders, display of the offer acceptance, or communication to the central or territorial structure of the preemptor identification data, or potential buyers.

The contravention fine is currently for all the above contraventions between 100,000 and 200,000 lei: Law no. 175/2020 doubled these fines.

\section{Civil law sanctions}

The sale of agricultural lands located outside the built-up area without respecting the right of preemption or the rights of favoured buyers or obtaining the approvals analysed above is prohibited and sanctioned with nullity. Before the amendments introduced by Law no. 175/2020, the sanction was that the contracts concluded by the violation of the preemption rights were voidable, the sanction of nullity being reserved for the situation in which the preemption right was not exercised and the building was sold at a lower price or in more advantageous conditions than those established through the sale offer brought to the attention of the preemptors.

The change of perspective is significant: the legal movement of agricultural land outside the built-up area has become a matter of public policy.

\section{Instead of conclusions: is this legal regime in line with European law?}

Law no. 175/2020 was subject to a constitutional review before promulgation. According to the Romanian Constitution, as a result of accession, the provisions of the European Union's constitutive treaties, as well as other mandatory community regulations, have priority over the contrary provisions of domestic law, in compliance with the provisions of the Act of Accession (Article 148 para. (2) of the constitution):

${ }^{28}$ See art. 14 of Law no. 17/2014, in the form established by Law no. 175/2020. 
Emőd Veress

Sale of agricultural lands located outside built-up area in Romania: novelty elements introduced by Law no. 175/2020
Journal of Agricultural and

Environmental Law

$30 / 2021$

The authors of the objection of unconstitutionality, in essence, argued that the law has as its "indirect objective the restriction of the right of citizens of the EU Member States and States party to the Agreement on the European Economic Area to acquire ownership of agricultural land outside built-up areas.' 29

The decision of the Romanian Constitutional Court (RCC) no. 586/2020 was adopted by a majority of votes. The constitutional judges who voted against formulated two separate opinions, in which they supported the unconstitutionality of this legislation. ${ }^{30}$

The majority opinion concluded that "the criticised provisions do not regulate any restriction or exclusion of natural or legal persons from the Member States from the purchase of agricultural land, but impose certain conditions for achieving the purpose of the law, namely the development of the land property. All these conditions are common to natural and legal persons in the Member States of the European Union, and there is no difference in legal treatment between them regarding the right to purchase agricultural land outside the built-up areas. The criticised texts do not forbid or exclude the right of natural or legal persons from outside the national territory to buy such lands, with the fulfilment of the conditions provided by law, equally valid conditions regarding Romanian natural or legal persons. Therefore, the above demonstrates that the legislator did not operate with the criterion of citizenship/nationality, but with a set of objective criteria aimed at the buyer's ability to maintain the category of use of extra-urban agricultural land and to work it effectively.' 31 The conclusion of a sales contract, as a buyer, presupposes a solid and well-defined material base on the national territory and a relevant work experience in the pedoclimatic conditions of Romania. It follows that the law does not establish arbitrary conditions to be able to buy agricultural land outside the built-up area but rather conditions that support the purpose of the law. ${ }^{32}$

Contrary to this majority view, the first separate opinion argues that a conditioning "by a law adopted in 2020 (...) of the acquisition of agricultural land located outside the built-up area by establishing the domicile/residence of the acquirer on national territory is equivalent to a restrictive measure for potential acquirers, although they are citizens of the European Union, do not have their domicile/ residence on the national territory, i.e., violate the commitments made by Romania towards the European Union as they result from point 3 of Annex VII to the Treaty on Accession of the Republic of Bulgaria and Romania to the European Union.' 33 The other separate opinion states that "the provisions criticised, although they do not regulate an express and direct exclusion of natural or legal persons from the Member States from the purchase of agricultural land located outside the built-up area, impose certain conditions which can be classified as having equivalent effect.' 34

${ }^{29}$ Point 18 of the RCC Decision no. 586/2020.

30 The decision and the separate opinions were published in the Official Gazette, Part I no. 721 of 11 August 2020.

31 Point 100 of the RCC Decision no. 586/2020.

32 Point 101 of the RCC Decision no. 586/2020.

33 Point 3.2.2. from the Separate Opinion formulated by Livia Doina Stanciu and Elena-Simina Tănăsescu.

${ }^{34}$ Point 2 of the Separate Opinion formulated by Mona-Maria Pivniceru. 
The position of the European Union is currently not definitively clarified. The European Commission has issued an interpretative communication, which is also based on the current state of the case-law of the European Court of Justice (CJEU). On the one hand, this communication recognises the specific importance of agricultural land and considers that the special regulation of agricultural land movement is justified, including certain accepted restrictions. However, on the other hand, many restrictions are considered inconsistent with European Union law. 35 With regard to residence requirements, the European Commission relied on Case C-452/01 Ospelt, paragraph 54 , in which it was held that the conditions under which the acquirer must reside on the purchased land were not legal, respectively, Case C-370/05, Festersen, paragraphs 35 and 40, in which the CJEU "considered as disproportionate the requirement that the acquirer takes up his fixed residence on the property which is the object of the sale. The CJEU found that such a residence requirement is particularly restrictive, given that it not only affects free movement of capital and freedom of establishment but also the right of the acquirer to choose his residence freely.' 36 Similarly, the CJEU held that national rules "under which a distinction is drawn based on residence in that non-residents are denied certain benefits which are, conversely, granted to persons residing within the national territory, are liable to operate mainly to the detriment of nationals of other Member States. Non-residents are in the majority of cases foreigners.' 37 Following the interpretative communication issued by the Commission, the CJEU ruled that "articles9, 10 and 14 of Directive 2006/123/EC of the European Parliament and of the Council of 12 December 2006 on services in the internal market must be interpreted as precluding legislation of a Member State which makes the right for a legal person to acquire agricultural land located in the territory of that Member State - in cases where the member or members who together represent more than half of the voting rights in the company, and all persons who are entitled to represent that company, are nationals of other Member States - conditional upon, first, submitting a certificate of registration of those members or representatives as residents of that Member State and, second, a document demonstrating that they have a knowledge of the official language of that Member State corresponding to a level which enables them to at least converse on everyday subjects and on professional matters" (case C-206/19, “KOB” SIA).

In the future, the compliance of this new Romanian regulation with European law will be verified. The separate opinions, a careful analysis of the European Commission's interpretative communication, foreshadow a solution of non-compliance of national with European law.

However, it is undeniable that public policy requirements, such as food security, the exploitation of natural agricultural resources in accordance with the national interest, and making these resources available to those who actually work in agriculture and who do not use the transfer of ownership of agricultural land for speculative investment purposes, require the adoption of serious restrictions on the legal

35 Commission interpretative communication on the acquisition of farmland and European Union law (2017 / C 350/05), published in the Official Journal of the European Union C 350 of 18.10.2017.

36 See Interpretative Communication, 15.

37 Cases C-279/93, Finanzamt Köln-Altstadt v Schumacker, paragraph 28; C-513/03, van Hilten-van der Heijden, paragraph 44; C-370/05, Festersen, paragraph 25; C-11/07, Eckelkamp, paragraph 46. See also the more recent solution in Case C-206/19, "KOB" SIA. 
Emőd Veress

Sale of agricultural lands located outside built-up area in Romania: novelty elements introduced by Law no. 175/2020
Journal of Agricultural and

Environmental Law

$30 / 2021$

movement of agricultural land, which cannot be regarded as mere goods whose freedom of movement is essential. This aspect should also be recognised and reflected in European law, both in its written form and in its form emanating from the European Court of Justice's case law.

In fact, in my opinion, this Romanian regulation is far from ideal for achieving the desired goals. A rethink will undoubtedly be needed from the perspective of European law in the process of formation in this field and the means used to achieve otherwise legitimate aims. Comparative law can offer pertinent solutions to be adapted to Romanian realities. ${ }^{38}$

38 For example, see the articles published in the CEDR Journal of Rural Law no. 1/2017. For the experience of the Central and Eastern European Countries, see in the cited journal especially the following articles: Yancheva et al. 2017, 29-32.; Damborský \& Snopková 2017, 38-42.; Raisz 2017, 68-74.; Budzinowski \& Suchoń 2017, 94-97.; Banderlová, Lazíková \& Palšová 2017, 98-103. 
Emőd Veress

Sale of agricultural lands located outside built-up area in

Romania: novelty elements introduced by Law no. 175/2020
Journal of Agricultural and

Environmental Law

$30 / 2021$

\section{Bibliography}

1. Banderlová A, Lazíková J \& Palšová L (2017) Slovakia, CEDR Journal of Rural Law 3(1), pp. 98-103.

2. Budzinowski R \& Suchoń A (2017) Poland, CEDR Journal of Rural Law 3(1), pp. 94-97.

3. Damborský M \& Snopková T (2017) Czech Republic, CEDR Journal of Rural Law 3(1), pp. 38-42.

4. Durnescu (Prăjanu) MG (2020) Era necesară modificarea Legii nr. 17/2014 ce reglementează vânzarea terenurilor agricole situate în extravilan?, Revista Universul Juridic 12/2020, pp. 37-57.

5. Jora C \& Ciochină-Barbu I (2018) Discuții referitoare la proiectul de modificare și completare a legii privind vânzarea terenurilor agricole situate în extravilan, Dreptul 8/2018, pp. 9-18.

6. Prescure T \& Spîrchez G-B (2020) Unele considerații referitoare la recentele modificări legislative în materia vânzării terenurilor agricole situate în extravilan, prin raportare la exigențele dreptului Uniunii Europene, Revista Universul Juridic 10/2020, pp. 21-40.

7. Raisz A (2017) Hungary, CEDR Journal of Rural Law 3(1), pp. 68-74.

8. Szilágyi JE (2017) General Report of Commission II, in: CEDR (ed.) CAP Reform: Market Organisation and Rural Areas, Nomos, Baden-Baden, pp. 214-250.

9. Yancheva C et al. (2017) Bulgaria, CEDR Journal of Rural Law 3(1), pp. 29-32. 